\title{
PARASITOLOGY
}

\author{
EDITED BY
}

GEORGE H. F. NUTTALL, F.R.S.

Quick Professor of Biology in the University of Cambridge

AND

ARTHUR E. SHIPLEY, F.R.S.

Reader in Zoology in the University of Cambridge

ASSISTED BY

EDWARD HINDLE, Рн.D.

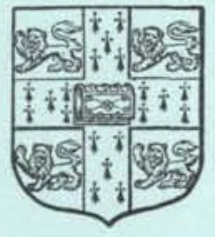

CAMBRIDGE

AT THE UNIVERSITY PRESS

LONDON: FETTER LANE. C. F. CLAY, MANager ALSO H. K. LEWIS, GOWER STREET

AND WHLIAM WESLEY AND SON, 28, ESSEX STREET, STRAND EDINBURGH : 100 , PRINCES STREET

BERLIN : A. ASHER \& CO.

LEIPSIC: BROCKHAUS

NEW YORK: G. P. PUTNAM's SONS

BOMBBAX AND CALCUTTA: MACMHUTAN \& CO., LTD.

Price Ten Shillings net

[Issued June 29, 1912] 


\title{
THE CLIMATE OF THE CONTINENT OF AFRICA
}

By ALEXANDER KNOX, B.A. (CANTAB.), F.R.G.S.

Royal 8vo. With 13 maps and a diagram

Price 21s. net

"Such a work as this has not only become highly necessary, but should be in great demand amongst Governments, mining and commercial companies trading in Afriea, missionary societies, and all individuals who intend to visit Africa for any length of time, or to settle in any part of that continent for purposes of health, science, education, or commercial gain... The maps contributed to this book by $\mathrm{Mr} \mathrm{J}$. G. Bartholomew under the direction of the author are admirable, and great praise must be awarded to the author for his general research, the clearness with which he sets forth his details and his conclusions, and the way in which he has invested what might seem to be a somewhat uninteresting subject with an interest and an importance sufficient to attract the general reader as well as the specialist. The book...should prove a standard work."-Sir H. H. JoHNston in Nature

\section{TICKS A Monograph of the Ixodoidea}

By GEORGE H. F. NUTTALL, M.D., Ph.D., Sc.D., F.R.S., CECIL WARBURTON, M.A., F.Z.S., W. F. COOPER, B.A., F.Z.S., F.L.S. and L. E. ROBINSON, A.R.C.Sc. (London)

\author{
Now ready $\left\{\begin{array}{l}\text { PART I. THE ARGASIDAE. 5s. net } \\ \text { PART II. THE IXODIDAE. 12s. net } \\ \text { BIBLIOGRAPHY OF THE IXODOIDEA. 6s. net }\end{array}\right.$
}

\section{THE}

\section{JOURNAL \\ OF HYGIENE PLAGUE SUPPLEMENT}

\author{
SIXTH REPORT ON PLAGUE \\ INVESTIGATIONS IN INDIA
}

\section{ISSUED BY THE ADVISORY COMMITTEE APPOINTED BY THE SECRETARY OF STATE FOR INDIA, THE ROYAL SOCIETY, AND THE LISTER INSTITUTE.}

206 pp. with 14 plates, 3 maps, 6 charts, etc. Price $7 s$. net

\section{CONTENTS}

XL. Major George Lamb, M.D. Glasg., I.M.S. With portrait

XLI. Epitome of some recent observations on rat-fleas

XLII. Preliminary observations on the protective and eurative value for rats of the serum of a horse immunised with a toxic nueleo-protein extracted from the plague bacillus

XLIII. Second report on investigations into plague vaceines

XIIV. Statistical investigation of plague in the Punjab. Second report: On the connection between proximity to railways and frequency of epidemics

XLV. Statistical investigation of plague in the Punjab. Third report: On some of the factors which influence the prevalence of plague

XLVI. Observations on plague in Eastern Bengal and Assam

XLVII. Observations on the breeding of Mus rattus in captivity 


\section{PARASITOLOGY}




\section{CAMBRIDGE UNIVERSITY PRESS}

Zlonion: FETTER LANE, E.C.

C. F. Clay, Manager

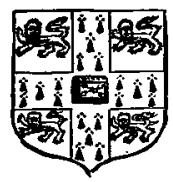

(ePdinburgh: 100, PRINCES STREET

Zlonton: H. K. LEWIS, 136, GOWER STREET, W.C.

WILLIAM WESLEY AND SON, 28, ESSEX STREET, STRAND

Berlín: A. ASHER AND CO.

lleipsig: F. A. BROCKHAUS

Chicaga: THE UNIVERSITY OF CHICAGo PRESS

Homban and Caltutta: MACMILI,AN AND CO, ITD.

All rights reserved 


\title{
PARASITOLOGY
}

\section{A SUPPLEMENT TO THE \\ JOURNAL OF HYGIENE}

\author{
EDITED BY
}

GEORGE H. F. NUTTALL, F.R.S.

Quick Professor of Biology in the University of Cambridge

AND

A. E. SHIPLEY, F.R.S.

Reader in Zoology in the University of Cambridge

ASSISTED BY

EDWARD HINDLE, Рн.D.

\section{Volume V I9I2-I3}

\author{
Cambridge \\ at the University Press \\ I 9 I 3
}




\section{Cambriong:}

PRINTED BY JOHN CLAY, M.A.

AT THE DNIVERSITY PRESS 


\title{
CONTENTS
}

\author{
No. 1 (February).
}

Warburton, Cecil. Notes on the Genus Rhipicephalus, with the

PAGE

Description of New Species, and the Consideration of some Species hitherto described. (With 12 Text-figures).

Watson, E. A. and Hadwen, S. Trypanosomes found in Canadian Mammals. (With Plates I and II) . . . . . . . 21

Southwel, T. The Ceylon Pearl Inducing Worm. A Brief Review of the Work done to date . . . . . . . . . .

Christophers, S. R. The Development of Leucocytozoon canis in the Tick with a Reference to the Development of Piroplasma. (With 2 Diagrams) . . . . . . . . . .

Schilling-Torgau, Dr V. Bemerkung zu der Arbeit Otto V. Huffinan: "The Kurloff-body, a Spurious Parasite". . .

Nutrall, George H. F. Notes on Ticks. II. (1) New Species (Amblyomma, Haemaphysalis). (2) Ixodes putus: Description of the hitherto unknown Larval Stage. (With 9 Text-figures) .

Nuttall, George H. F. Note on Rossiella rossi (Nuttall, 1910) occurring in the Jackal in British East Africa . . .

Nuttall, George H. F. and Strickland, C. On the Occurrence of two Species of Parasites in Equine "Piroplasmosis" or "Biliary Fever." (With Plate III, 8 Diagrams, 1 Text-figure and 5 Charts)

No. 2 (June).

Strickland, C. Agrippina bona nov. gen. et nov. sp. representing a New Family of Gregarines. (With Plate IV and 33 Text-figures)

Hindle, Edward and Lewis, R. C. Note on "Crithidia" cleti n. sp., Parasitic in the Alimentary Canal of Cletus varius Dall. (With 17 Text-figures) . . . . . . . . . . 
Govgh, Lewis Henry. The Anatomy of Stilesia globipunctata (Rivolta). (With 2 Text-figures) . . . . . . 114

Stiles, C. W. Third List of Generic Names for the "Official List of Zoological Names" . . . . . . . . . . 118

Balfour, Andrew. The Life-cycle of Spirochaeta gallinarum. An Appreciation and a Criticism of Dr E. Hindle's Recent Paper

Hindle, Edward. What is the Genus Leptomonas Kent? . . 128

Bayon, H. The Experimental Transmission of the Spirochaete of European Relapsing Fever to Rats and Mice. (With 3 Textfigures) . . . . . . . . . . . . 13

Mitter, S. N. Note on Gnathostomum spinigerum. (With Plate V) 150

Nuttall, George H. F. In Memoriam. Adelchi Negri. (With Portrait, Plate VI) . $\quad . \quad$. $\quad . \quad$. $\quad . \quad$. $\quad . \quad$. 151

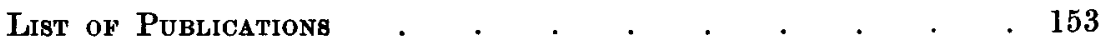

Publications Received . . . . . . . . . . 155

\section{No. 3 (September).}

Hewitt, C. Gordon. Fannia (Homalomyia) canicularis Linn. and F. scalaris Fab. An Account of the Bionomics and the Larvae of the Flies and their Relation to Myiasis of the Intestinal and Urinary Tracts. (With Plate VII and 7 Text-figures) . .

Mackinnon, Doris L. Protists Parasitic in the Larva of the CraneFly, Tipula sp. (Preliminary note.) (With 27 Text-figures) .

Henry, Herbert. Haemogregarina anarrhichadis from Anarrhichas lupus, the Catfish. (With Plate VIII) . . . . . . 190

Nicoll, William. On two new Trematode Parasites from British Food-fishes. (With Plate IX) • . . . . . . . . . . 197

Hindle, Edward and Merriman, Gordon. The Sensory Perceptions of Argas persicus (Oken). (With 2 Diagrams) . . . . 203

Innes, J. Alexander. Gastrothylax bubalis n. sp. with a few Notes on the Genus Gastrothylax (Poirier). (With 8 Text-figures) . 


\section{No. 4 (January)}

Acton, Hugn W. and Harvey, W. F. The Fixation of Rabies Virus in the Monkey (Macacus rhesus) with a Study of the Appearance of Negri Bodies in the different Passages. (With Plate X) . $\quad 227$

Hadwen, Seymovr. The Life-history of Dermacentor variabilis . 234

Nicoll, William. New Trematode Parasites from Fishes of the English Channel. (With Plate XI) . . . . . . 238

Coles, Alfred C. Trypanosomes found in a Cow in England. (With Plate XII)

Nutrall, George H. F. In Memoriam. Wilhelm Dönitz. (With Portrait, Plate XIII) . . . . . . . . .

PAGE

Nutrall, George H. F. The Herter Lectures. I. Spirochaetosis. Lecture delivered on the Herter Foundation, Johns Hopkins University, Baltimore, Maryland, U.S.A. 8 October, 1912 .

Nuttall, George H. F. The Herter Lectures. II. Trypanosomiasis. Lecture delivered on the Herter Foundation, Johns Hopkins University, Baltimore, Maryland, U.S.A. 9 October, 1912 .

Dschunkowsky, E. und Luhs, T. Nuttallia und Piroplasma bei der Piroplasmose der Einhufer in Transkaukasien. (With Plates $\mathrm{XIV}$ and XV) . . . . . . . . . . 289

INDEX OF AUThors . . . . . . . . . . . . . 303

INDEX OF SUbJECTS . 